\title{
PENGARUH SELF EFFICACY DAN EMPLOYEE EMPOWERMENT PADA KEPUASAN KERJA MELALUI EMPLOYEE ENGAGEMENT PADA PT. ASTRA INTERNASIONAL TBK - ASTRA ISUZU MEDAN (CABANG SM RAJA)
}

\author{
Tika Nurjanah ${ }^{1 *}$, Tapi Rondang Ni Bulan ${ }^{2}$, Sarah Imelda ${ }^{3}$ \\ 1,2,3 Fakultas Ekonomi Bisnis, Universitas Harapan Medan, Medan Indonesia \\ Jl. Imam Bonjol No.35, Jati, Kec. Medan Maimun, Kota Medan, Sumatera Utara, 20152 \\ *Penulis korespondensi; Email: Tapinibulan@gmail.com¹, Tikanrjh07@gmail.com², Sarahimelda84@gmail.com
}

\begin{abstract}
Abstrak
Penelitian ini bertujuan untuk mengetahui pengaruh self efficacy pada kepuasan kerja melalui employee engagement dan untuk mengetahui pengaruh employee empowerment pada kepuasan kerja melalui employee engagement. Populasi dalam penelitian ini adalah karyawan PT. Astra Internasional Tbk. - Astra Isuzu Medan (Cabang SM Raja) yang berjumlah 120 orang. Teknik analisis yang digunakan adalah regresi linier berganda. Hasil penelitian menunjukkan bahwa self efficacy berpengaruh positif dan signifikan pada kepuasan kerja yang dimediasi oleh employee engagement. Empolyee empowerment berpengaruh positif dan signifikan pada kepuasan kerja yang dimediasi oleh employee engagement.
\end{abstract}

Kata Kunci: Self efficacy, employee empowerment, kepuasan kerja, employee engagement.

\begin{abstract}
This study aimed to determine the effect of self-efficacy on job satisfaction through employee engagement and to determine the effect of employee empowerment on job satisfaction through employee engagement. The population in this study were 120 employees of PT. Astra International Tbk. - Astra Isuzu Medan (SM Raja Branch). The analysis technique used is multiple linear regression. The results showed that the self-efficacy had a positive and significant effect on job satisfaction mediated by employee engagement. The employee empowerment had a positive and significant effect on job satisfaction mediated by employee engagement
\end{abstract}

Keywords: Self efficacy, employee empowerment, job satisfaction, employee engagement.

\section{Pendahuluan}

Aset yang paling berharga dan paling penting yang menentukan keberhasilan suatu organisasi adalah sumberdaya manusia (SDM). Manajemen SDM pada umumnya digunakan untuk memperoleh tingkat perkembangan karyawan yang maksimal, hubungan kerja yang serasi di antara karyawan dan penyatu paduan sumberdaya manusia secara efektif, sehingga diharapkan dapat meningkatkan produktivitas kerja yang baik. Saat ini menjadi persoalan awal perusahaan yaitu bagaimana menciptakan SDM yang berkompeten yang membuat karyawan merasa puas atas pekerjaan yang dilakukannya, karena karyawan yang merasa puas dengan pekerjaannya akan bekerja lebih produktif dan setia dengan organisasinya. Menurut Rizal (dalam Agustina, 2016) kepuasan kerja yaitu kepekaan yang dirasakan seseorang perihal pekerjaan yang disukai atau tidak disukai.

Berdasarkan wawancara dengan salah satu karyawan PT. Astra Internasional Tbk. - Astra Isuzu Medan (Cabang SM Raja), pada Maret tahun 2021 perusahaan telah melakukan pengukuran kepuasan kerja melalui pengisian angket/kuesioner. Hasil pengukuran ini menyatakan bahwa para karyawan akan merasakan puas terhadap pekerjaannya apabila mampu menyelesaikan pekerjaan dengan baik, memperoleh gaji yang tinggi, memiliki kesempatan untuk naik jabatan, memiliki hubungan kerja yang baik antar sesama rekan kerja serta komunikasi yang baik antara atasan dan bawahan. Tabel 1 menunjukkan persentase rating kinerja karyawan. 
Tabel 1

Persentase Rating Kinerja Kerja Karyawan PT. Astra Internasional Tbk. Astra Isuzu Medan (Cabang SM Raja)

\begin{tabular}{cccccc}
\hline Rating & A & B & C & D & E \\
\hline 2019 & $17 \%$ & $52 \%$ & $24 \%$ & $7 \%$ & $0 \%$ \\
2020 & $16 \%$ & $54 \%$ & $26 \%$ & $4 \%$ & $0 \%$ \\
\hline
\end{tabular}

Sumber: data olahan PT. Astra Internasional Tbk. - Astra Isuzu Medan (Cabang SM Raja)

Dari Tabel 1 memperlihatkan karyawan yang mendapatkan rating nilai B mendominasi karyawan PT. Astra Internasional Tbk. - Astra Isuzu Medan (Cabang SM Raja) sebesar 52\% ditahun 2019 dan terjadi peningkatan persentase pada tahun 2020 sebesar $2 \%$, pada tahun 2019. Yang mencapai rating A atau yang diharapkan perusahaan hanya sebesar $17 \%$ dan berubah atau mengalami penurunan persentase sebesar $1 \%$ pada tahun 2020 . Tabel 1 juga memperlihatkan terjadi peningkatan persentase yang mendapatkan nilai $\mathrm{C}$ sebesar $2 \%$ di tahun 2020, dan penurunan persentase D sebesar 3\% dari tahun 2019 ke tahun 2020. Pada tahun 2020 terjadi penurunan jumlah karyawan yang berpredikat istimewa dan meningkatan jumlah karyawan yang berpredikat baik dan predikat memuaskan pada tahun 2020 juga menurun.

PT. Astra Internasional Tbk. - Astra Isuzu Medan (Cabang SM Raja) menyadari bahwa kepuasan kerja karyawan di dalam perusahaan menurun. Salah satunya muncul yaitu kontak antar rekan kerja. Hal ini terjadi dalam kondisi kerja yang canggung dan kurang kondusif juga program pencapaian kerja yang tidak tepat. Untuk mencapai kepuasan kerja perlu memperkuat self efficacy setiap individu. Self efficacy adalah keyakinan bahwa seseorang dapat melaksanakan beberapa tindakan dan mencapai beberapa hasil dengan sukses. Yakin dan Erdil (dalam Agustina 2016) menyatakan bahwa individu memiliki tingkat self efficacy yang tinggi lebih berupaya melampaui posisi sulit daripada individu memiliki tingkat self efficacy yang rendah.

Karyawan perusahaan diharapkan memiliki self efficacy tinggi yang dapat memotivasi untuk berkembang dan bukan menjadi penghalang. Setiap karyawan harus memiliki kemampuan dan pengetahuan dalam menyelesaikan permasalahan dalam pekerjaan dan mampu menemukan solusi yang tepat dalam menangani masalah yang sedang dihadapi. Persoalan employee empowerment pada PT. Astra Internasional Tbk. - Astra Isuzu Medan (Cabang SM Raja) dalam hasil wawancara dengan karyawan yaitu belum dilakukannya pemberdayaan karyawan secara terus-menerus, sehingga karyawan tidak mempunyai kebebasan untuk melakukan pekerjaan secara inovatif yang menimbulkan kejenuhan dalam bekerja. Bagaimana membangun kepercayaan antara atasan dan bawahan harus dipertimbangkan untuk memberdayakan karyawan. Karyawan harus diberi peluang untuk berpartisipasi dalam melaksanakan kebijakan dan ikut dalam pelatihan untuk kebutuhan kerja mereka, ini dapat meningkatkan kapasitas karyawan untuk menyelesaikan pekerjaan yang diberikan.

Persoalan employee empowerment pada PT. Astra Internasional Tbk. - Astra Isuzu Medan (Cabang SM Raja) dalam hasil wawancara dengan karyawan yaitu belum dilakukannya pemberdayaan karyawan secara terusmenerus, sehingga karyawan tidak mempunyai kebebasan untuk melakukan pekerjaan secara inovatif yang menimbulkan kejenuhan dalam bekerja. Bagaimana membangun kepercayaan antara atasan dan bawahan harus dipertimbangkan untuk memberdayakan karyawan. Karyawan harus diberi peluang untuk berpartisipasi dalam melaksanakan kebijakan dan ikut dalam pelatihan untuk kebutuhan kerja mereka, ini dapat meningkatkan kapasitas karyawan untuk menyelesaikan pekerjaan yang diberikan. Saling mengenal perbedaan satu sama lain akan menjadi kunci sukses yang bermanfaat karena pekerja merasa dihargai oleh atasan.

Natrajan et al. (dalam Asri 2020) menerangkan yaitu upaya dalam melibatkan karyawan di suatu organisasi, dapat menjadikan karyawan tersebut agar lebih produktif karena merasa diakui di suatu organisasi, juga akan berpengaruh kepada tujuan utama dari organisasi. Halim (2013) memaparkan bahwa kondisi para pekerja di Indonesia yaitu hanya 36\% karyawan yang (engaged), $17 \%$ (not engaged) yang menimbulkan risiko potensial untuk produktivitas dan kinerja. Di samping itu, 23\% lainnya merasa tidak mendapatkan dukungan saat bekerja atau digolongkan karyawan yang hampir terikat (engaged) sisanya digolongkan dalam kelompok memisahkan diri.

Penerapan employee empowerment dan employee engagement di organisasi mendorong karyawan merasa terikat dan bersemangat dalam pekerjaannya. Employee engagement menjadi prioritas karena adanya keterikatan karyawan terhadap perusahaan maka dapat memicu karyawan dalam bekerja dan berinovasi dengan lebih baik lagi. 


\section{Kajian Teoritis dan Hipotesis Self Efficacy}

Self efficacy yaitu hasil proses kognitif sosial yang berwujud keyakinan dan harapan serta keputusan pada kemampuannya dalam bertindak untuk mendapatkan hasil yang puas (Bandura dalam Lau, 2015). Menurut Indrawati (dalam Khaerana, 2020) terdapat beberapa indikator self efficacy, sebagai berikut:

1. Keyakinan akan kemampuannya dalam melaksanakan pekerjaan.

2. Kemampuan yang lebih baik daripada orang lain.

3. Tantangan akan pekerjaan.

4. Kepuasan akan pekerjaan

\section{Employee Empowerment}

Conger dan Kanungo (dalam Soelton et al., 2021) mendefinisikan pemberdayaan karyawan (employee empowerment) adalah pegangan untuk memperluas keahlian diri dari beberapa bagian organisasi dengan mengenali keadaan yang melemahkan individu dan setelah itu terbebas dari kondisi tersebut yang ditunjukkan untuk menambah informasi yang meluas. Menurut Priansa (dalam Lestari \& Siregar, 2021) indikator employee empowerment, sebagai berikut:

1. Keinginan

2. Kepercayaan

3. Kredibilitas

4. Akuntabilitas

5. Komunikasi

\section{Kepuasan Kerja}

Menurut Dewi dan Lubis (2020), kepuasan kerja adalah suatu sikap karyawan yang merasa puas terhadap pekerjaannya dan ditandai dengan perasaan senang, giat, tekun, dan cinta terhadap pekerjaan yang dikerjakan, sehingga menghasilkan sesuai apa yang diharapkan dengan apa yang diterimanya. Adapun indikator kepuasan kerja menurut Widodo (dalam Harahap \& Tritayasa, 2020), antara lain:

1. Gaji

2. Pekerjaan itu sendiri

3. Rekan kerja

4. Atasan

5. Promosi

\section{Employee Engagement}

Employee engagement merupakan rasa memiliki hubungan yang energik dan efektif dengan kegiatan kerja, dan melihat diri mampu menangani dengan baik tuntutan pekerjaan (Pusriadi \& Darma, 2020). Menurut Schaufeli (dalam Ilman, 2020) ada tiga indikator employee engagement, di antaranya yaitu:

1. Semangat (Vigor)

2. Dedikasi (Dedication)

3. Penyerapan (Absorption)

\section{Pengaruh Self Efficacy pada Kepuasan Kerja Melalui Employee Engagement}

Macey et al. (dalam Arianti, Hubies, \& Puspitawati, 2020) menjelaskan employee engagement suatu perasaan individu terhadap tujuan dan dorongan terfokus jelas, dalam daya pikiran pribadi, kemampuan beradaptasi, usaha dan ketekunan yang diarahkan pada tujuan organisasi. Sangat penting bagi pimpinan perusahaan untuk memperkuat employee engagement, karena karyawan not engaged telah kehilangan motivasi kerja, dan akan mendorong peningkatan turnover. Karyawan yang memiliki employee engagement akan menciptakan kepuasan kerja yang maksimal.

Menurut Dewi dan Lubis (2020) kepuasan kerja adalah suatu sikap karyawan yang merasa puas terhadap pekerjaannya dan ditandai dengan perasaan senang, giat, tekun dan cinta terhadap pekerjaan yang dikerjakan, sehingga menghasilkan sesuai apa yang diharapkan dengan apa yang diterimanya. Semakin tinggi tingkat kepuasan yang dirasakan seseorang, maka semakin banyak aspek dalam pekerjaan yang sesuai dengan kepentingan dan harapan individu tersebut, dan semakin rendah tingkat kepuasan yang dirasakan seseorang maka semakin rendah pula aspek dalam pekerjaan yang sesuai dengan kepentingan dan harapannya. Selain employee engagement karyawan yang memiliki self efficacy juga sangat memengaruhi kepuasan kerja. 
Self efficacy sebagai keyakinan individu mampu melaksanakan pekerjaan tertentu yang memengaruhi latihan seseorang untuk mencapai tujuannya (Bandura dalam Ramohan \& Agung, 2020). Tingginya self efficacy membuat karyawan berupaya mengerjakan tugas yang sulit dengan tetap tenang dan tidak ragu, sehingga mampu meningkatkan kepuasan kerja. Tanpa self efficacy yang besar dalam diri seseorang, pencapaian karyawan tidaklah ideal.

Self efficacy mempunyai pengaruh yang signifikan pada employee engagement, employee engagement mempunyai pengaruh yang signifikan pada kepuasan kerja. Hubungan antar variabel self efficacy mempunyai pengaruh langsung pada variabel kepuasan kerja. Hal ini menunjukkan bahwa variabel employee engagement mampu memediasi variabel self efficacy pada kepuasan kerja.

$H_{l}$ : Self efficacy berpengaruh positif pada kepuasan kerja yang dimediasi oleh employee engagement

\section{Pengaruh Employee Empowerment pada Kepuasan Kerja Melalui Employee Engagement}

Employee engagement merupakan keadaan seseorang terlibat secara aktif terhadap pekerjaanya, serta hendak melakukan kesediaan untuk mendukung perusahaan, sehingga mereka dengan penuh hati melakukan pekerjaannya dengan baik. Menurut Marciano (dalam Cintani \& Noviansyah, 2020) karyawan engaged akan berkomitmen pada tujuan maupun sepenuh kemampuannya untuk menyelesaikan tugas, menjaga sikapnya saat bekerja, memastikan bahwa sudah menyelesaikan tugas dengan tuntas sesuai dengan tujuan dan bersedia mengambil langkah perbaikan atau penilaian jika memang diperlukan. Karyawan yang engaged akan memengaruhi kepuasan kerja yang besar dalam pekerjaannya.

Kepuasan kerja juga mempunyai kontribusi yang besar pada peningkatan maupun semangat kerja dari berbagai karyawan. Setiap orang akan memiliki tingkat kepuasaan yang berbeda beda sesuai dengan sistem nilai yang berlaku pada dirinya. Semakin tinggi tingkat kepuasan yang dirasakan seseorang maka semakin banyak aspek dalam pekerjaan yang sesuai dengan kepentingan dan harapan individu tersebut, dan semakin rendah tingkat kepuasan yang dirasakan seseorang maka semakin rendah pula aspek dalam pekerjaan yang sesuai dengan kepentingan dan harapannya. Tentu saja seseorang yang merasakan kepuasan kerja sudah pasti mempunyai tingkat percaya diri dan kemampuan yang tinggi karena adanya employee empowerment di dalam dirinya.

Pengaruh employee empowerment pada employee engagement signifikan dan employee engagement pada kepuasan kerja juga signifikan, begitupun pengaruh employee empowerment pada kepuasan kerja juga signifikan mengartikan bahwa employee engagement mampu menjadi variabel mediator secara parsial employee empowerment dalam pengaruhnya pada kepuasan kerja. Hasil ini menunjukkan bahwa employee engagement mampu menjadi variabel mediasi pengaruh employee empowerment pada kepuasan kerja.

$\mathrm{H}_{2}$ : Employee empowerment berpengaruh positif pada kepuasan kerja yang dimediasi oleh employee engagement.

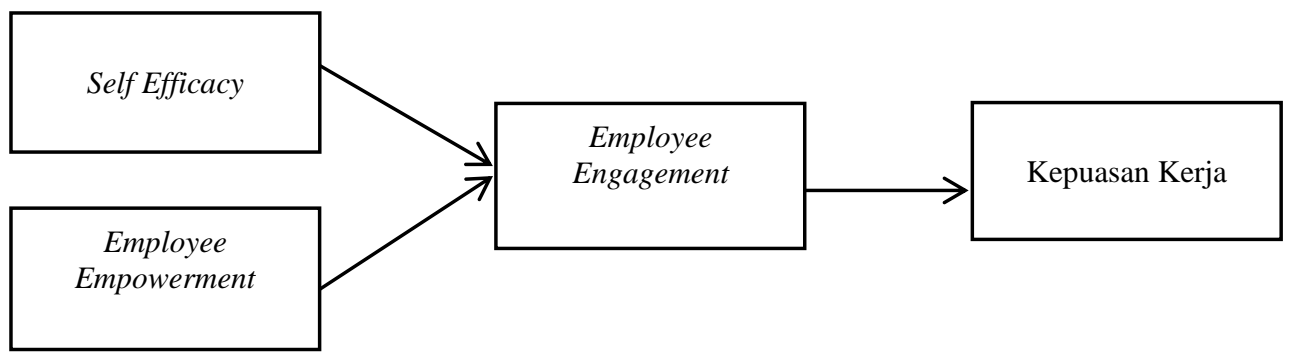

Gambar 1. Kerangka konseptual

\section{Self Efficacy $\left(X_{I}\right)$}

\section{Metode Penelitian Definisi Operasional Variabel}

Self efficacy merupakan suatu penilaian individu akan kemampuan pada dirinya sendiri untuk melakukan suatu perilaku atau untuk mewujudkan tujuan tertentu (Ormrod dalam Lestari, Karim, \& Sari, 2021). Indikator yang digunakan dalam penelitian ini (Yuel \& Keintjem, 2021), yaitu:

1. Level/magnitude

2. Generallity 


\section{Strength}

\section{Employee Empowerment $\left(X_{2}\right)$}

Employee empowerment merupakan suatu tema utama dari kegiatan manajemen terkait dengan praktek kepemimpinan yang saling mendukung untuk kemudian dapat membuat organisasi menjadi lebih kompetitif (Moye \& Henkin dalam Soelton et al., 2021). Indikator yang digunakan dalam penelitian ini (Priansa dalam Lestari \& Siregar, 2021), yaitu:

1. Keinginan

2. Kepercayaan

3. Kepercayaan diri

4. Kredibilitas

5. Akuntabilitas

6. Komunikasi

\section{Kepuasan $\operatorname{Kerja}(Y)$}

Kepuasan kerja adalah suatu sikap karyawan yang merasa puas terhadap pekerjaannya dan ditandai dengan perasaan senang, giat, tekun dan cinta terhadap pekerjaan yang dikerjakan, sehingga menghasilkan sesuai apa yang diharapkan dengan apa yang diterimanya (Dewi \& Lubis, 2020). Indikator yang digunakan dalam penelitian ini (Widodo dalam Harahap \& Tirtayasa, 2020), yaitu:

1. Gaji

2. Pekerja itu sendiri

3. Rekan kerja

4. Atasan

5. Promosi

6. Lingkungan kerja

\section{Employee Engagement}

Employee engagement suatu perasaan individu terhadap tujuan dan dorongan terfokus jelas, bagi orang lain dalam tampilan daya pikiran pribadi, kemampuan beradaptasi, usaha dan ketekunan yang diarahkan pada tujuan organisasi (Macey et al. dalam Arianti et al., 2020). Indikator yang digunakan dalam penelitian ini (Schaufeli dalam Ilman, 2020), yaitu:

1. Semangat (vigor)

2. Dedikasi (dedication)

3. Penyerapan (absorption)

Menurut Sugiyono (dalam Effendi, 2021) populasi adalah wilayah generalisasi yang terdiri atas objek/subjek yang mempunyai kualitas dan karakteristik tertentu yang ditetapkan oleh peneliti untuk dipelajari dan kemudian ditarik kesimpulannya. Berdasarkan pengertian tersebut populasi dalam penelitian ini adalah karyawan yang bekerja di PT. Astra Internasional Tbk. - Astra Isuzu Medan (Cabang SM Raja) berjumlah 120 Karyawan. Responden ialah seluruh populasi.

\section{Analisis Data dan Pembahasan \\ Karakteristik Responden Berdasarkan Jenis Kelamin}

Berdasarkan hasil dari penyebaran kuesioner kepada 120 responden, diperoleh gambaran responden berdasarkan jenis kelamin seperti terlihat dalam Tabel 2. Dalam penelitian ini jumlah responden yaitu 120 orang. Responden yang terbanyak bekerja di PT. Astra Internasional Tbk. - Astra Isuzu Medan (Cabang SM Raja) yaitu berjenis kelamin laki-laki sebesar 83 responden dengan persentase $69,2 \%$, dan responden berjenis kelamin perempuan sebesar 37 responden dengan persentase 30,8\%. 
Tabel 2

Karakteristik Responden Berdasarkan Jenis Kelamin

\begin{tabular}{lcc} 
Jenis Kelamin & Jumlah & Persentase (\%) \\
\hline Laki-Laki & 83 & 69,2 \\
Perempuan & 37 & 30,8 \\
\hline \multicolumn{1}{c}{ Total } & 120 & 100 \\
\hline
\end{tabular}

\section{Hasil Uji Validitas}

Berikut disajikan hasil pengujian validitas untuk setiap butir kuesioner penelitian yang terdapat pada variabel di PT. Astra Internasional Tbk. - Astra Isuzu Medan (Cabang SM Raja) pada Tabel 3-Tabel 6.

Tabel 3

Hasil Uji Validitas Self Efficacy $\left(X_{I}\right)$

\begin{tabular}{cccc}
\hline Pernyataan & R-hitung & R-tabel & Validitas \\
\hline Butir 1 & 0,679 & & Valid \\
Butir 2 & 0,770 & & Valid \\
Butir 3 & 0,601 & \multirow{2}{*}{0,178} & Valid \\
Butir 4 & 0,702 & & Valid \\
Butir 5 & 0,504 & & Valid \\
Butir 6 & 0,492 & & Valid \\
\hline
\end{tabular}

\section{Tabel 4}

Hasil Uji Validitas Employee Empowerment $\left(\mathrm{X}_{2}\right)$

\begin{tabular}{cccc}
\hline Pernyataan & R-hitung & R-tabel & Validitas \\
\hline Butir 1 & 0,675 & & Valid \\
Butir 2 & 0,643 & & Valid \\
Butir 3 & 0,593 & \multirow{2}{*}{0,178} & Valid \\
Butir 4 & 0,752 & & Valid \\
Butir 5 & 0,675 & & Valid \\
Butir 6 & 0,749 & & Valid \\
\hline
\end{tabular}

Tabel 5

Hasil Uji Validitas Employee Engagement $(Z)$

\begin{tabular}{cccc}
\hline Pernyataan & R-hitung & R-tabel & Validitas \\
\hline Butir 1 & 0,675 & & Valid \\
Butir 2 & 0,738 & & Valid \\
Butir 3 & 0,620 & \multirow{2}{*}{0,178} & Valid \\
Butir 4 & 0,691 & & Valid \\
Butir 5 & 0,781 & & Valid \\
Butir 6 & 0,755 & & Valid \\
\hline
\end{tabular}

Tabel 6

Hasil Uji Validitas Kepuasan $\operatorname{Kerja}(Y)$

\begin{tabular}{cccc}
\hline Pernyataan & R-hitung & R-tabel & Validitas \\
\hline Butir 1 & 0,726 & & Valid \\
Butir 2 & 0,752 & \multirow{2}{*}{0,178} & Valid \\
Butir 3 & 0,703 & & Valid \\
Butir 4 & 0,715 & & Valid \\
\hline
\end{tabular}

Berdasarkan hasil Tabel 3-Tabel 6 menunjukkan bahwa butir pernyataan pada variabel self efficacy, employee empowerment, employee engagement, dan kepuasan kerja mempunyai nilai $R$-hitung $>$ R-tabel $(0,178)$ dapat disimpulkan seluruh item kuesioner dinyatakan valid dan dapat dijadikan acuan untuk penelitian selanjutnya. 


\section{Hasil Uji Reliabilitas}

Uji Reliabilitas dilakukan pengujian dengan memakai bantuan komputer program SPSS, dengan rumus Cronbach's Alpha $>0,60$, maka data dianggap sangat baik atau reliabel. Hasil pengujian reliabilitas ( $r$ Alpha) terhadap semua variabel dapat dirangkum pada Tabel 7.

\section{Tabel 7}

Hasil Uji Reliabilitas Variabel

\begin{tabular}{lccc}
\hline \multicolumn{1}{c}{ Variabel } & Cronbach's Alpha & Nilai Standar & Hasil \\
\hline SelfEfficacy $\left(X_{l}\right)$ & 0,692 & & \\
Employee Empowerment $\left(X_{2}\right)$ & 0,765 & 0,60 & Reliabel \\
Employee Engagement $(Z)$ & 0,801 & & \\
Kepuasan Kerja $(Y)$ & 0,692 & & \\
\hline
\end{tabular}

Berdasarkan pada Tabel 7 bahwa nilai Cronbach's Alpha pada variabel self efficacy $\left(X_{I}\right)$ sebesar 0,692, variabel employee empowerment $\left(X_{2}\right)$ sebesar 0,765 , variabel employee engagement $(Z)$ sebesar 0,801 , dan variabel kepuasan kerja $(Y)$ sebesar 0,692 . Dari hasil keseluruhan pada variabel masing-masing mempunyai nilai Cronbach's Alpha $>0,60$. Berarti bahwa seluruh variabel dinyatakan reliabel.

\section{Uji F (Uji Kelayakan Model) Regresi 1}

Berdasarkan Tabel 8 diperoleh nilai $F$-hitung sebesar 61,192. Nilai $F$-tabel dengan taraf signifikansi 0,00 dengan $d f_{1}=k-1=2-1=1$ dan $d f_{2}=n-k=120-2=118$ diperoleh sebesar 3,07 dan nilai signifikansi sebesar 0,000. Hasil F-hitung > F-tabel $(61,192>3,07)$ dan nilai Sig. $<0,05(0,00<0,05)$, maka dapat disimpulkan bahwa Model Regresi 1 layak menjelaskan pengaruh variabel self efficacy dan employee engegement pada kepuasan kerja.

\section{Tabel 8}

Uji $F$ Regresi 1 (ANOVA)

\begin{tabular}{clccccc}
\hline Model & & Sum of Squares & $\boldsymbol{d} \boldsymbol{f}$ & Mean Square & $\boldsymbol{F}$ & Sig. \\
\hline \multirow{1}{*}{$\mathbf{n}$} & Regression & 310,223 & 2 & 155,112 & 61,192 & $0,000^{\mathrm{b}}$ \\
& Residual & 296,577 & 117 & 2,535 & & \\
& Total & 606,800 & 119 & & & \\
\hline
\end{tabular}

a. Dependent Variable: Kepuasan Kerja

b. Predictors: (Constant), Employee Engagement, Self Efficacy

Uji t (Uji Hipotesis) Regresi 1

Berdasarkan hasil uji $t$ di Tabel 9 dapat dikembangkan Model Regresi 1, sebagai berikut:

$$
Y=1,128+0,234 X_{l}+0,381 Z+e
$$

Tabel 9

Hasil Uji $t$ (Uji Hipotesis) Regresi 1

\begin{tabular}{|c|c|c|c|c|c|c|}
\hline \multirow{2}{*}{ Model } & & \multicolumn{2}{|c|}{ Unstandardized Coefficients } & \multirow[b]{2}{*}{ Standardized Coefficients Beta } & \multirow[b]{2}{*}{$t$} & \multirow{2}{*}{ Sig. } \\
\hline & & $\boldsymbol{B}$ & Std. Error & & & \\
\hline \multirow[t]{3}{*}{1} & (Constant) & 1,128 & 1,450 & & 0,777 & 0,438 \\
\hline & Employee Engagement & 0,381 & 0,057 & 0,509 & 6,704 & 0,000 \\
\hline & Self Efficacy & 0,234 & 0,059 & 0,302 & 3,976 & 0,000 \\
\hline
\end{tabular}

Dependent Variable: Kepuasan Kerja

yang bermakna:

a) Variabel Self Efficacy $\left(X_{I}\right)$

Nilai $t$-hitung untuk variabel self efficacy adalah 3,976 dengan nilai sig. 0,000. Sementara nilai $t$-tabel dengan taraf signifikansi 0,05 dan $d f=n-k=120-2=118$, diperoleh 1,980 . Nilai sig. $0,000<0,05$ yang berarti signifikan. Penelitian uji t-hitung 3,976 > t-tabel 1,980, maka hipotesis diterima. Hasil disimpulkan bahwa self efficacy berpengaruh terhadap kepuasan kerja.

b) Variabel Employee Engagement ( $Z$ )

Nilai $t$-hitung untuk variabel employee engagement adalah 6,704 dengan nilai sig. 0,000 . Sementara nilai $t$ tabel dengan taraf signifikan 0,05 dan $d f=n-k=120-2=118$, diperoleh 1,980. Nilai sig. $0,000<0,05$ dan 
hasil uji t-hitung 6,704 > t-tabel 1,980 artinya hipotesis diterima. Berdasarkan hasil uji tersebut disimpulkan bahwa employee engagement berpengaruh positif dan signifikan terhadap kepuasan kerja.

\section{Koefisien Determinasi Regresi 1}

Berdasarkan hasil Tabel 10 diketahui bahwa besarnya nilai korelasi atau hubungan $R$ sebesar 0,503 dan dijelaskan besarnya persentase pengaruh variabel dependen dengan koefisien determinasi yang merupakan hasil pengkuadratan dari $R$. Hasil output tersebut diperoleh koefisien determinasi $\left(R^{2}\right)$ sebesar 0,503 , artinya pengaruh self efficacy, employee engagement terhadap kepuasan kerja sebesar 50,3\% sedangkan sisanya dipengaruhi variabel lainnya.

Tabel 10

Uji Koefisien Determinasi Regresi 1

\begin{tabular}{ccccc}
\hline Model & $\boldsymbol{R}$ & $\boldsymbol{R}$ Square & Adjusted $\boldsymbol{R}$ Square & Std. Error of the Estimate \\
\hline $\mathbf{1}$ & $0,715^{\mathrm{a}}$ & 0,511 & 0,503 & 1,592 \\
\hline
\end{tabular}

a. Predictors: (Constant), Employee Engagement, Self Efficacy

b. Dependent Variable: Kepuasan Kerja

Uji F (Uji Kelayakan Model) Regresi II

Berdasarkan hasil Tabel 11 diperoleh nilai $F$-hitung sebesar 67,029. Nilai $F$-tabel dengan taraf signifikansi 0,05 dengan $d f_{1}=k-1=2-1=1$ dan $d f_{2}=n-k=120-2=118$ diperoleh sebesar 3,07 dan nilai signifikansi sebesar 0,000. Hasil F-hitung > F-tabel $(67,029>3,07)$ dan nilai Sig. $<0,05(0,000<0,05)$, maka dapat disimpulkan bahwa Model Regresi 2 layak menjelaskan pengaruh variabel employee empowerment, employee engagement pada kepuasan kerja.

Tabel 11

Uji F (Uji Kelayakan Model) Regresi II (ANOVA)

\begin{tabular}{ccccccc}
\hline Model & & Sum of Squares & df & Mean Square & $\boldsymbol{F}$ & Sig. \\
\hline $\mathbf{2}$ & Regression & 324,015 & 2 & 162,007 & 67,029 & $0,000^{\mathrm{b}}$ \\
& Residual & 282,785 & 117 & 2,417 & & \\
\hline \multicolumn{2}{c}{ Total } & 606,800 & 119 & & & \\
\hline
\end{tabular}

a. Dependent Variable: Kepuasan Kerja

b. Predictors: (Constant), Employee Engagement, Employee Empowerment

\section{Uji t (Uji Parsial) Regresi II}

Berdasarkan hasil uji $t$ di Tabel 12, maka dapat dikembangkan model regresi, sebagai berikut:

$$
Y=1,137+0,293 X_{2}+0,317 Z+e
$$

Tabel 12

Hasil Uji $t$ (Uji Hipotesis) Regresi II

\begin{tabular}{|c|c|c|c|c|c|c|}
\hline \multirow{2}{*}{\multicolumn{2}{|c|}{ Model }} & \multicolumn{2}{|c|}{ Unstandardized Coefficients } & \multirow{2}{*}{$\begin{array}{c}\text { Standardized Coefficients } \\
\text { Beta }\end{array}$} & \multirow{2}{*}{$t$} & \multirow[b]{2}{*}{ Sig. } \\
\hline & & $B$ & Std. Error & & & \\
\hline \multirow[t]{3}{*}{2} & (Constant) & 1,137 & 1,370 & & 0,830 & 0,408 \\
\hline & Employee Engagement & 0,293 & 0,62 & 0,384 & 4,721 & 0,000 \\
\hline & Employee Empowerment & 0,317 & 0,61 & 0,424 & 5,214 & 0,000 \\
\hline
\end{tabular}

Dependent Variable: Kepuasan Kerja

yang bermakna:

a) Variabel Employee Empoerment $\left(X_{2}\right)$

Nilai $t$-hitung untuk variabel employee empowerment adalah 4,721 dengan nilai sig. 0,000 . Sementara nilai $t$ tabel dengan taraf signifikan 0,05 dan $d f=n-k=120-2=118$, diperoleh 1,980 . Nilai sig. $0,000<0,05$ yang berarti signifikan. Penelitian uji t-hitung 4,721 >t-tabel 1,980, maka hipotesis diterima. Hasil disimpulkan bahwa employee empowerment berpengaruh terhadap kepuasan kerja, artinya setiap menurunnya employee empowerment, maka menurunnya kepuasan kerja.

b) Variabel Employee Engagement (Z) 
Nilai $t$-hitung untuk variabel employee engagement adalah 5,214 dengan nilai sig. 0,000. Sementara nilai ttabel dengan taraf signifikan 0,05 dan $d f=n-k=120-2=118$, diperoleh 1,980. Nilai sig. $0,000<0,05$ dan hasil uji t-hitung 5,214>t-tabel 1,980 artinya hipotesis diterima. Berdasarkan hasil uji tersebut disimpulkan bahwa employee engagement berpengaruh positif dan signifikan terhadap kepuasan kerja.

\section{Koefisien Determinasi Regresi II}

Berdasarkan hasil Tabel 13 diketahui bahwa besarnya nilai korelasi atau hubungan $R$ sebesar 0,526 dan dijelaskan besarnya persentase pengaruh variabel dependen dengan koefisien determinasi yang merupakan hasil pengkuadratan dari $R$. Hasil output tersebut diperoleh koefisien determinasi $\left(R^{2}\right)$ sebesar 0,526 , artinya pengaruh employee empowerment, employee engagement terhadap kepuasan kerja sebesar 52,6\% sedangkan sisanya dipengaruhi variabel lainnya.

\section{Tabel 13}

Uji Koefisien Determinasi Regresi II

\begin{tabular}{ccccc}
\hline Model & $\boldsymbol{R}$ & $\boldsymbol{R}$ Square & Adjusted $\boldsymbol{R}$ Square & Std. Error of the Estimate \\
\hline $\mathbf{1}$ & $0,731^{\mathrm{a}}$ & 0,534 & 0,526 & 1,555 \\
\hline
\end{tabular}

a. Predictors: (Constant), Employee Engagement, Employee Empowerment

b. Dependent Variable: Kepuasan Kerja

\section{Pembahasan}

\section{Pengaruh Self Efficacy Pada Kepuasan Kerja Melalui Employee Engagement}

Berdasarkan hasil penelitian menunjukan bahwa self efficacy berpengaruh pada kepuasan kerja yang dimediasi oleh employee engagement. Hal ini dibuktikan dengan hasil signifikan sebesar 0,000<0,05. Berarti Ho ditolak dan $\mathrm{Ha}$ diterima.

Ini membuktikan bahwa self efficacy berpengaruh langsung positif pada kepuasan kerja yang dimediasi oleh employee engagement (Agustina, 2016). Hal ini bermakna bahwa tinggi rendahnya self efficacy yang dimiliki oleh karyawan di PT. Astra Internasional Tbk. - Astra Isuzu Medan (Cabang SM Raja) akan sangat menentukan pada kemampuan dirinya dalam menggerakkan sumberdaya kognitif dan cara bertindak untuk dapat berhasil menjalankan suatu pekerjaan seperti dapat melaksanakan pekerjaan, dapat menyelesaikan pekerjaan, dapat mencapai tujuan, dapat memotivasi diri dan dapat mengatasi tantangan, dan selanjutnya pada diri karyawan tersebut akan muncul employee engagement atau keterikatan karyawan pada pekerjaannya.

Kepuasan kerja karyawan merupakan sebuah umpan balik yaitu pekerjaan yang memungkinkan karyawan untuk melaksanakan pekerjaan yang dilakukan secara tekun dan gembira sesuai rencana kerja dan menentukan tujuannya sendiri yang akan meningkatkan kepercayaan diri karyawan dan dengan demikian akan meningkatkan perasaan kognitif kegembiraan dalam bekerja. Karyawan yang memiliki self efficacy tinggi akan menjadi lebih puas dengan pekerjaan mereka, dan akan berkomitmen untuk pekerjaannya, termotivasi untuk tampil baik pada pekerjaan dan dalam program pelatihan daripada karyawan yang memiliki self efficacy rendah.

\section{Pengaruh Employee Empowerment Pada Kepuasan Kerja Melalui Employee Engagement}

Berdasarkan hasil penelitian menunjukkan bahwa employee empowerment berpengaruh pada kepuasan kerja yang dimediasi oleh employee engagement. Hal ini dibuktikan dengan hasil signifikan sebesar $0,000<0,05$. Berarti Ho ditolak dan Ha diterima.

Employee empowerment dijelaskan sebagai kemampuan karyawan yang memungkinkan karyawan untuk memperkuat dan mengembangkan konstituen yang ada didalam diri karyawan PT. Astra Internasional TbkAstra Isuzu Medan (Cabang SM Raja). Employee empowerment memiliki peran penting dalam meningkatkan kinerja perusahaan (Elnaga \& Imran, 2015). Hal ini dikarenakan empowerment merupakan satu satunya cara yang efektif untuk membantu karyawan dalam meningkatkan kemampuan dan kreatifitasnya yang berguna dalam penyelesaian pekerjaannya.

Seseorang yang memiliki kepuasan kerja dan employee engagement menandakan orang tersebut akan setia dengan pekerjaan yang memuaskannya dan berhenti dari pekerjaan yang tidak memuaskannya. Penelitian Ameer, Bhatti, dan Baig (2014) juga menyimpulkan bahwa employee empowerment berpengaruh positif signifikan pada kepuasan kerja yang dimediasi oleh employee engagement. Artinya apabila employee empowerment meningkat maka kepuasan kerja dan employee engagement juga akan meningkat. Begitu juga 
sebaliknya, penurunan employee empowerment mampu menurunkan kepuasan kerja dan employee engagement pada karyawan PT. Astra Internasional Tbk. - Astra Isuzu Medan (Cabang SM Raja).

\section{Simpulan, Keterbatasan, dan Saran \\ Simpulan}

Tujuan dilakukannya penelitian ini adalah untuk mengetahui pengaruh dari self efficacy, employee empowerment pada kepuasan kerja melalui employe engagement pada PT. Astra Internasional Tbk. - Astra Isuzu Medan (Cabang SM Raja). Berdasarkan hasil uji analisis regresi yang telah dilakukan, maka dapat disimpulkan yaitu variabel self efficacy berpengaruh positif dan signifikan pada kepuasan kerja yang dimediasi oleh employee engagement pada PT. Astra Internasional Tbk. - Astra Isuzu Medan (Cabang SM Raja). Variabel employee empowerment berpengaruh positif dan signifikan pada kepuasan kerja melalui employee engagement pada PT. Astra Internasional Tbk. - Astra Isuzu Medan (Cabang SM Raja).

\section{Keterbatasan}

Penelitian selanjutnya agar dapat mencari dan menambahkan variabel yang dapat memengaruhi kepuasan kerja seperti pengetahuan dan keterampilan, ketepatan waktu dan komunikasi, sehingga dapat diketahui variabel apa saja yang dapat memengaruhi kepuasan kerja secara representatif dan mampu memprediksi kinerja karyawan dengan lebih akurat.

\section{Saran}

Berdasarkan hasil penelitian yang dilakukan pada PT. Astra Internasional Tbk. - Astra Isuzu Medan (Cabang SM Raja), maka beberapa saran-saran yaitu perusahaan hendaknya tetap menjaga tingginya tingkat kepuasan kerja pada PT. Astra Internasional Tbk. - Astra Isuzu Medan (Cabang SM Raja). Cara yang dapat dilakukan untuk meningkatkan kepuasan kerja karyawan antara lain dengan meningkatkan self efficacy, employee empowerment dan keterikatan karyawan meliputi kemampuan diri, pengawasan diri, dan kepercayaan diri pada karyawan PT. Astra Internasional Tbk. - Astra Isuzu Medan (Cabang SM Raja), sehingga karyawan merasa akan menjadi lebih puas dengan pekerjaan mereka, dan akan berkomitmen untuk pekerjaannya, termotivasi untuk tampil baik pada pekerjaan dan dalam program pelatihan lainnya.

\section{Referensi}

Agustina, N. (2016). Pengaruh self-efficacy dan locus of control terhadap kepuasan kerja karyawan PT. Perkebunan Nusantara (PTPN) X Surabaya. Jurnal Ilmu Manajemen, 4(1), 1-11.

Ameer, M. H., Bhatti, S., \& Baig, S. (2014). Impact of employee empowerment on job satisfaction. Developing Country Studies, 4(9), 114-125

Arianti, W. P., Hubies, M., \& Puspitawati, H. (2020). Pengaruh faktor kepuasan kerja terhadap employee engagement di Perwiratama Group. Jurnal Manajemen Teori dan Terapan, 13(1), 31-48. http://dx.doi.org/ 10.20473/jmtt.v13i1.14889

Asri, D. H. (2020). Pengaruh employee empowerment terhadap employee performance dengan employee engagement sebagai mediasi. Jurnal Rekaman: Riset Ekonomi Bidang Akuntansi dan Manajemen, 4(2), 231-237.

Cintani, C., \& Noviansyah, N. (2020). Pengaruh employee engagement terhadap kinerja karyawan pada PT. Sinar Kencana Multi Lestari. Kolegial: Jurnal Manajemen, Bisnis, dan Akuntansi, 8(1), 29-44.

Dewi, R. H., \& Lubis, D. S. W. (2020). Pengaruh kepuasan kerja dan lingkungan kerja terhadap tingkat turn over karyawan pada STIM Sukma Medan. Civitas: Jurnal Studi Manajemen, 2(2), 64-70.

Elnaga, A., \& Imran, A. (2013). The effect of training on employee performance. European Journal of Business and Management, 5(4), 137-147.

Harahap, S. F., \& Tirtayasa, S. (2020). Pengaruh motivasi, disiplin dan kepuasan kerja terhadap kinerja karyawan pada PT. Angkasa Pura II (Persero) Kantor Cabang Kualanamu. MANEGGIO: Jurnal Ilmiah Magister Manajemen, 3(1), 120-135.

Ilman, F. (2020). Pengaruh employee engagement and self efficacy terhadap kinerja karyawan. Skripsi, Universitas Islam Negeri Syarif Hidayatullah. 
Khaerana. (2020). Pengaruh self efficacy terhadap kinerja pegawai pada sekretariat Komisi Pemilihan Umum Daerah (KPUD) Kabupaten Luwu Timur. Jurnal Ecoment Global: Kajian Bisnis dan Manajemen, 5(1), 80-89. http://dx.doi.org/10.35908/jeg.v5i1.835

Lestari, D. K., \& Siregar, H. (2021). Pemberdayaan karyawan terhadap kepuasan kerja karyawan pada PT. Rotella Persada Mandiri Lubuk Pakam. ARBITRASE: Journal of Economics and Accounting, 1(3), 125129.

Lestari, S. A., Karim, K., \& Sari, A. (2021). Analisis self efficacy matematis dan hasil belajar matematika siswa SMPN sekota Banjarmasin. Jurmadikta (Jurnal Mahasiswa Pendidikan Matematika), 1(1), 68-76.

Pusriadi, T., \& Darma, D. C. (2020). Pengaruh talent management dan employee engagement terhadap employee capabilities: Studi pada karyawan PT. Bintang Wahana Tata. Jurnal Riset Entrepreneurship, 3(1), 54-61. http://dx.doi.org/10.30587/jre.v3i1.1317

Ramohan, A., \& Agung, I. S. (2020). Model peningkatan kinerja sdm melalui kepuasan kerja, self efficacy dan motivasi kerja di restauran S2 Semarang. Konferensi Ilmiah Mahasiswa Unissula (Kimu) 4, 1303.

Soelton, M., Erica, L. D., Wahyono, T., Yuliantini, T., Oktaviar, C., \& Arief, H. (2021). Variabel employee empowerment psychological contract dan job insecurity: Manakah yang paling berpengaruh terhadap organizational citizenship behavior di Jakcloth Indonesia? Prosiding Conference on Economic and Business Innovation, 1(1), 1-13.

Yuel, Y., \& Keintjem, C. (2021). Self efficacy dan kemandirian belajar pendidikan agama Kristen siswa di SMAN 1 Palangka Raya. Harati: Jurnal Pendidikan Kristen, 1(1), 101-114. https://doi.org/10.54170/ harati.v1i1.35. 